\title{
Improving of Green Sand-Mould Quality using Taguchi Technique
}

DOI:10.36909/jer.14079

\author{
Sampath Boopathi* \\ *Department of Mechanical Engineering, Muthayammal Engineering College, Rasipuram, \\ Tamil Nadu 637408. \\ *Email: boopasangee@gmail.com; Corresponding Author.
}

\begin{abstract}
The green sand mould casting is an inevitable process to make large size and complex shape of the industrial components. The quality of green sand in mould is a significant phenomenon on casting quality. In this research, the number of ramming, sand thickness mould, and percentage of additives (western bentonite) mixing with sand have been considered to study the effects on permeability and hardness of mould by L27 orthogonal array. Greensand mould experiments have been conducted in the industry to observe the output parameter variations by Taguchi statistical analysis. It was revealed that the maximum permeability and minimum sand hardness have been obtained from the minimum number of ramming, thin sand thickness, and minimum mixing of additives in the sand. The confirmation tests were conducted to validate the predicted control parameter on responses.
\end{abstract}

Key words: wall thickness; additive mixture; number of ramming; hardness; Mould sand; permeability; Taguchi method. 


\section{INTRODUCTION}

In the foundry industries, the casting defect has been varying from 6 to $7 \%$ of total rejections. The causes of these defects were recorded by the improper forming of mould cavities. The most common defects were caused by pinholes, penetration, roughcasting surface, and washes of mould sand. In large-scale industries, the mould cavities are formed by high-pressure moulding instruments. The short holes, modern gating methods are used to improve the mould quality to reduce the various casting defects(Kotas et al., 2010). Due to the lack of time and high production pressure, making a vent hole is critical. The permeability of the mould extremely has been reduced by placing the unwanted riser, high hardness, and insufficient vent holes(Parappagoudar et al., 2007a). The controlling parameters of permeability had been studied as sand size, mould gap, clay quality, hardness, vent holes, and moisture quantity. It was revealed that the number of ramming will make the changes on compression, permeability and bulk strength (Ihom et al., 2009). These measures of green sand mould system have been analyzed by response surface methodology(Parappagoudar et al., 2007b). It was also revealed that the casting quality can be improved by reducing wall thickness due to the easy escaping of hot gases from cavity (Abdullah et al., 2012). The results obtained that the permeability of mould sand will be improved by adding additives with water due to reducing in bonding strength (Chang \& Hocheng, 2001). The green sand moulding control parameters such as clay quantity, moisture, bumping, sand size, and permeability were predicted using the Taguchimethod. Later, few kinds of research were performed to minimize the castings defects through Taguchi design of experiment, multi-functional analysis, and various non-conventional optimization techniques(Desai et al., 2016; Guharaja et al., 2006; Kumar et al., 2011; Kumaravadivel \& Natarajan, 2013; Nandagopal et al., 2020; Pattnaik et al., 2013; Pulivarti \& Birru, 2018; Santhosh \& Lakshmanan, 2016). Hence, the many green sand mould experimental types of research have been made to reduce the casting defects on some 
parameters.

As per the aforementioned literature, a few types of research have been made to optimize the green sand moulding control parameters. In this work, Taguchi L27 orthogonal array has been applied to optimize the mould sand characteristics to enhance the quality of mould cavity. The permeability and hardness of mould sand have been considered as response parameters which can be improved by varying the number of ramming, wall thickness, and the percentage of western bentonite with water. The Taguchi analysis is used to identify the significant control parameters to identify the influences of permeability and hardness. Finally, the Taguchi analysis is used to predict the optimum control factors to select the best characterises. And the results were practically evaluated by cast iron castings produced from modern large machines in industry.

\section{EXPERIMENTAL SETUP AND PROCEDURES}

The $84 \%$ sand, $3 \%$ water, $3 \%$ fresh sand, $1 \%$ bentokol are constantly maintained to prepare the mould sand. Initially, the exploratory experiments were conducted to select the range of control parameters for the systematic studies. The $5 \mathrm{~cm}$ diameter test component with different heights of 3,5, and $7 \mathrm{~cm}$ were prepared. The numbers of ramming are taken as 3, 5, and 7 times from moulding machine. The tolerance of specimen height is maintained as $\pm 1 \mathrm{~mm}$. Then, the permeability of the specimens was measured by permeability tester and the component hardness was measured by hardness measuring instruments. It was observed that the sand good hardness and low permeability have been obtained at minimum height. Control parameters and their levels for the Taguchi design are selected and shown in Table 1. The orthogonal array L9 and L27 are suitable for three levels of three parameters Taguchi analysis (Boopathi, 2019; Boopathi et al., 2012; Boopathi \& Myilsamy, 2021; Boopathi \& Sivakumar, 2013, 2014, 2016; Myilsamy \& Sampath, 2021; Sampath \& Myilsamy, 2021). In this study, the 
L27 orthogonal array has been selected and the Mean value of three replication of testing are observed in the Table 2 .

Table 1 Level and designation of control parameters

\begin{tabular}{|c|c|c|c|c|c|}
\hline Control parameter & $\begin{array}{c}\text { Factors } \\
\text { Symbol }\end{array}$ & Unit & Value 1 & Value 2 & Value 3 \\
\hline Number of ramming & A & - & 3 & 5 & 7 \\
\hline Wall thickness of Mould & B & $\mathrm{mm}$ & 30 & 50 & 70 \\
\hline Percentage of Additives & C & $\%$ & 8.5 & 9.0 & 9.5 \\
\hline
\end{tabular}

Table 2 Experimental observations by Taguchi Method

\begin{tabular}{|c|c|c|c|c|c|}
\hline \multirow{2}{*}{ Exp No. } & \multicolumn{3}{|c|}{ Control parameters } & \multicolumn{2}{|c|}{ Experimental observation } \\
\hline & $\mathbf{A}$ & B & $\mathbf{C}$ & $\begin{array}{c}\text { Permeability } \\
\text { Number (P) }\end{array}$ & $\begin{array}{c}\text { Hardness } \\
\text { Number }(\mathbf{H})\end{array}$ \\
\hline 1 & 3 & 30 & 8.5 & 202 & 83 \\
\hline 2 & 3 & 30 & 9.0 & 190 & 86 \\
\hline 3 & 3 & 30 & 9.5 & 180 & 87 \\
\hline 4 & 3 & 50 & 8.5 & 163 & 83 \\
\hline 5 & 3 & 50 & 9.0 & 139 & 86 \\
\hline 6 & 3 & 50 & 9.5 & 134 & 87 \\
\hline 7 & 3 & 70 & 8.5 & 128 & 82 \\
\hline 8 & 3 & 70 & 9.0 & 119 & 84 \\
\hline 9 & 3 & 70 & 9.5 & 115 & 85 \\
\hline 10 & 5 & 30 & 8.5 & 173 & 89 \\
\hline 11 & 5 & 30 & 9.0 & 153 & 90 \\
\hline 12 & 5 & 30 & 9.5 & 149 & 91.5 \\
\hline 13 & 5 & 50 & 8.5 & 142 & 85 \\
\hline 14 & 5 & 50 & 9.0 & 134 & 87 \\
\hline 15 & 5 & 50 & 9.5 & 122 & 88 \\
\hline 16 & 5 & 70 & 8.5 & 99 & 86 \\
\hline 17 & 5 & 70 & 9.0 & 93 & 87 \\
\hline 18 & 5 & 70 & 9.5 & 90 & 88 \\
\hline 19 & 7 & 30 & 8.5 & 138 & 90 \\
\hline 20 & 7 & 30 & 9.0 & 130 & 91 \\
\hline 21 & 7 & 30 & 9.5 & 126 & 92.5 \\
\hline 22 & 7 & 50 & 8.5 & 96 & 91 \\
\hline 23 & 7 & 50 & 9.0 & 90 & 92 \\
\hline 24 & 7 & 50 & 9.5 & 86 & 93 \\
\hline 25 & 7 & 70 & 8.5 & 90 & 89 \\
\hline 26 & 7 & 70 & 9.0 & 88 & 90 \\
\hline 27 & 7 & 70 & 9.5 & 83 & 91 \\
\hline
\end{tabular}




\section{TAGUCHI ANALYSIS}

Taguchi analysis is applied to predict the optimum control parameters for both responses. The mean hardness and permeability values (raw data) are considered to find the best level of the control parameters by Taguchi analysis(Boopathi \& Sivakumar, 2013; Myilsamy \& Sampath, 2021; Sampath \& Myilsamy, 2021). The maximization of permeability is taken as Larger as better and average hardness is expected as nominal as better (Boopathi, 2019). The analysis of variation test was performed for both responses. The ANOVA table for Permeability and hardness is shown in Tables 3 and 4 respectively(B. Long et al., 2016; B. T. Long et al., 2016; Nguyen et al., 2019). The effects of each parameter on permeability and hardness are illustrated in Figures 1 and 2 respectively(Boopathi et al., 2012; Myilsamy \& Sampath, 2021). It was detected that mould wall thickness (B) is $54.31 \%$ of contribution on permeability number. Hence Factor B is the most significant factor. The number of ramming (A) is $36.43 \%$ of contribution on Permeability. Parameter A is the second significant factor. It was revealed from Table 4 that the ramming quantity (A) and percentage of Addictive (C)are having $70.841 \%$ and $14.056 \%$ contributions on hardness.

Table 3 Taguchi Analysis of Permeability Number (P)

\begin{tabular}{|c|c|c|c|c|c|c|}
\hline Control parameter & DoF & Seq. SS & Adj. SS & Adj. MS & $\begin{array}{c}\text { F- } \\
\text { Value }\end{array}$ & $\begin{array}{c}\text { Contribution } \\
(\%)\end{array}$ \\
\hline A & 2 & 10906 & 10906 & 5452.93 & 72.03 & 36.4347 \\
\hline B & 2 & 16293 & 16293 & 8146.70 & 107.61 & 54.43156 \\
\hline C & 2 & 1220 & 1220 & 610.04 & 8.06 & 4.075769 \\
\hline Error & 20 & 1514 & 1514 & 75.70 & - & - \\
\hline Total & 26 & 29933 & - & - & - & - \\
\hline
\end{tabular}


Table 4 Taguchi Analysis of Hardness

\begin{tabular}{|c|c|c|c|c|c|c|}
\hline Control parameter & DoF & Seq. SS & Adj. SS & Adj. MS & $\begin{array}{c}\text { F- } \\
\text { value }\end{array}$ & $\begin{array}{c}\text { Contribution } \\
(\%)\end{array}$ \\
\hline A & 2 & 177.35 & 177.35 & 88.6759 & 89.84 & 70.841 \\
\hline B & 2 & 18.07 & 18.07 & 9.0370 & 9.16 & 7.2179 \\
\hline C & 2 & 35.19 & 35.19 & 17.5926 & 17.82 & 14.056 \\
\hline Error & 20 & 19.74 & 19.74 & 0.9870 & - & - \\
\hline Total & 26 & 250.35 & - & - & - & - \\
\hline
\end{tabular}

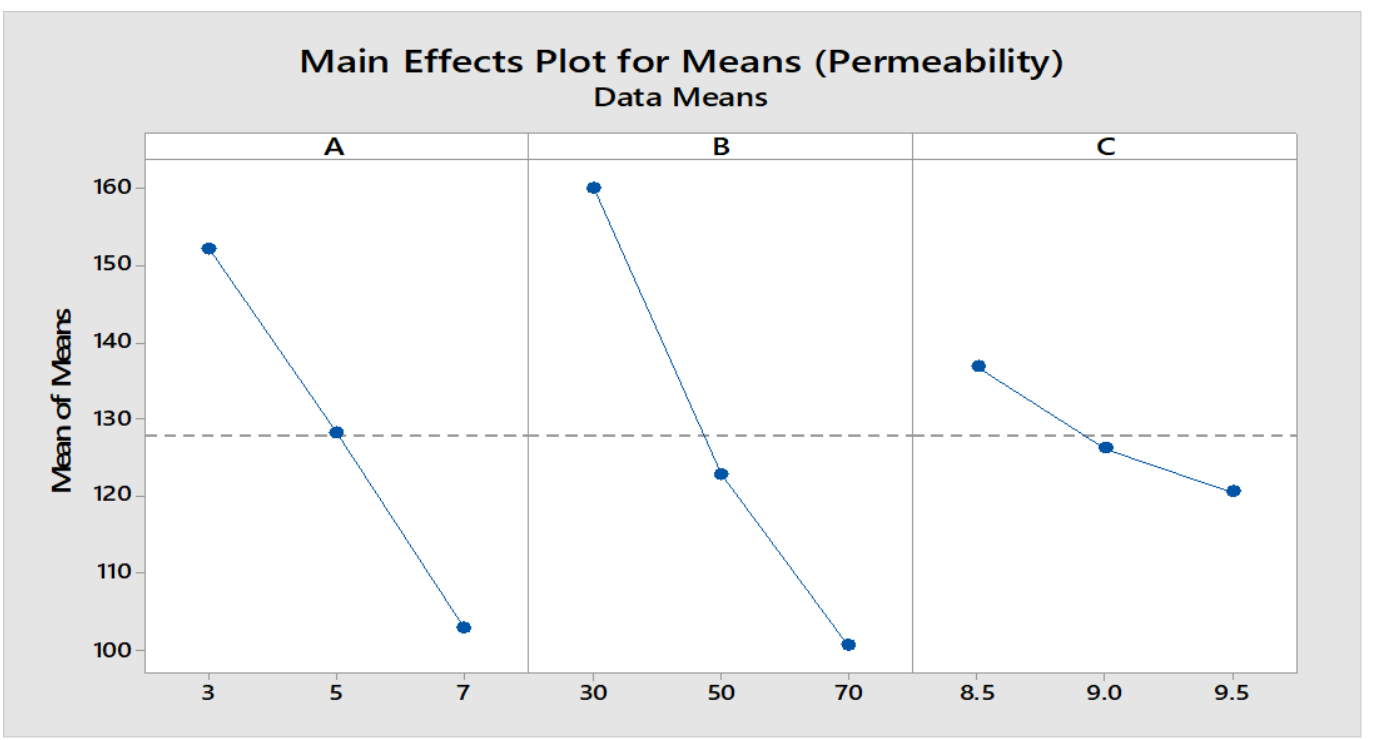

Figure 1 Effect of control parameters on Permeability

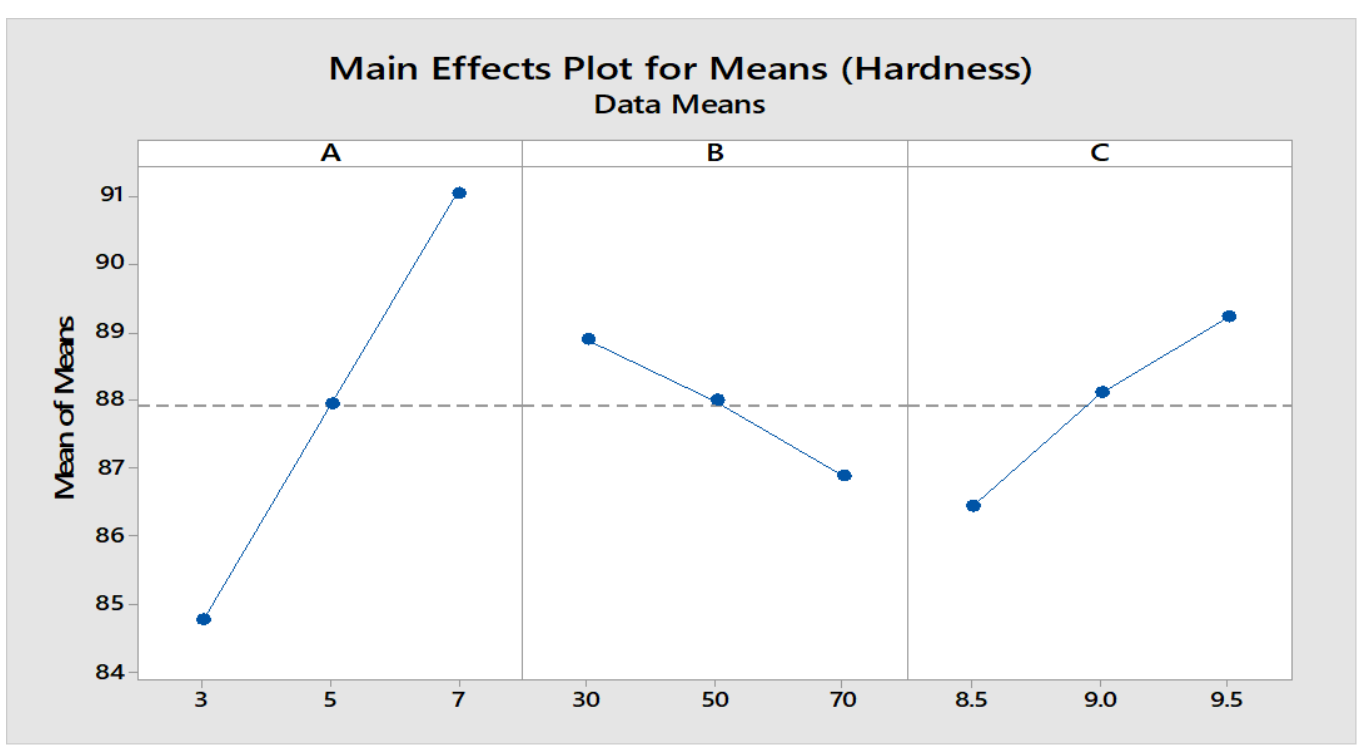

Figure 2 Effect of green sand control parameters on Hardness 


\section{ANALYSIS OF PREDICTED OPTIMUM LEVELS AND CONFIRMATION TEST}

The optimal level of permeability is highlighted based on higher is better. The optimum combination levels of each control parameter are $\mathrm{A}_{1} \mathrm{~B}_{1} \mathrm{C}_{1}$ based on Taguchi analysis as displayed in Table 5. The effect of control parameters levels based on analysis on the permeability is shown in Figure 1. The Taguchi analysis shows that the predicted permeability is 193.4 at the $90 \%$ confidence level. To ensure the quality of estimated control parameters level, the validation test is performed. The casting products are prepared based on the estimated values of control parameters $\mathrm{A}_{2} \mathrm{~B}_{2} \mathrm{C}_{2}$ on hardness. Taguchi analysis shows that the predicted hardness is 88.20 at the $95 \%$ confidence level. Table 5 shows the comparison between the initial setting test, confirmation test with predicted values. It shows that the confirmation test result closely correlates with the predicted result.

Table 5 Validation test results

\begin{tabular}{|l|l|l|l|l|}
\hline S.No. & Response & $\begin{array}{l}\text { Control parameter } \\
\text { Level }\end{array}$ & Predicted Value & $\begin{array}{l}\text { Confirmation } \\
\text { Test }\end{array}$ \\
\hline 1. & Hardness & A2B2C 2 & 88.20 & 88 \\
\hline 2 & Permeability & A1B1C1 & 193.4 & 193 \\
\hline
\end{tabular}

The time for escaping casting gases from mould is high due to thick mould walls, high hardness, and low permeability factors. The hardness improvement in casting is important for welding and machining processes(Haribalaji et al., 2015). Due to this problem, the backpressure of gas will make the blow holes in the casting and reduce the pouring rate of molten metals into the cavity, which causes the casting faults such as air-holes, pin-holes, misrun, and roughcasting surface. Existing mould cavity design in the industry is shown in Figure 3.

The optimum combination levels of each control parameter are $A_{1} B_{1} C_{1}$ and $A_{2} B_{2} C_{2}$ on permeability and hardness respectively. The following remedial activities were practically done 
to enhance the quality of the existing flange moulding process. The modified green sand mould design is shown in Figure 4.

The following improvements were achieved as:

- The mould permeability number increased significantly to the proper allowability of gas from mould cavity.

- The surface finish of the outer wall of the casting had been improved with minimum backpressure formation by increasing permeability number.

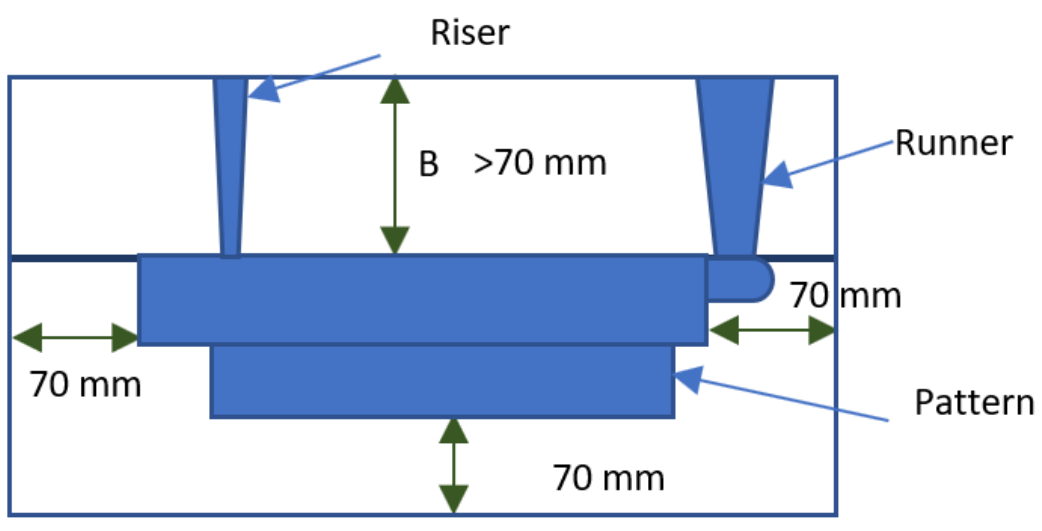

Figure 3 Existing mould cavity layout for pressure plate casting

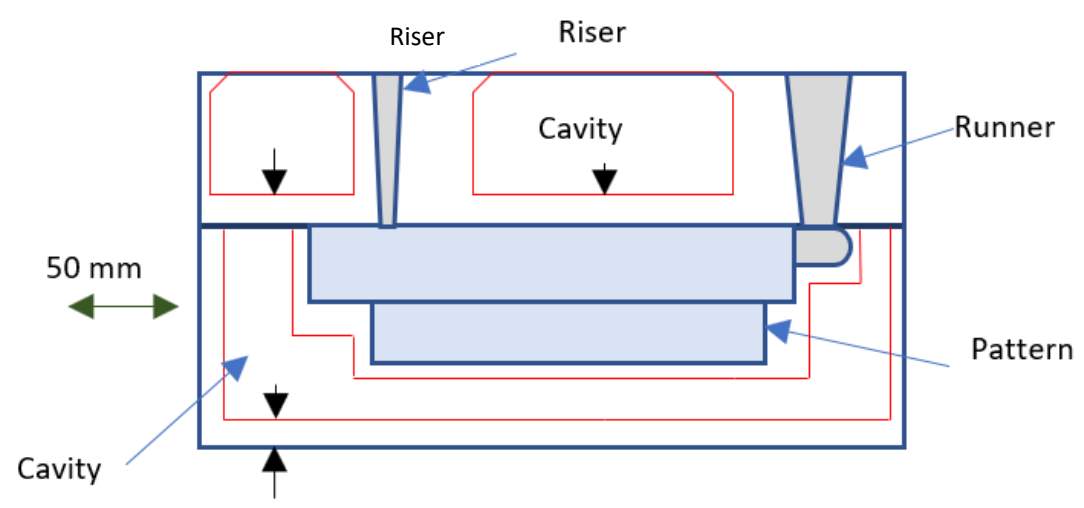

Figure 4 Modified mould cavity layout for flange casting 


\section{CONCLUSIONS}

Based on the Taguchi-analysis, the following conclusions are summarized. Mould wall thickness (B) is $54.31 \%$ of contribution on permeability number. Hence Factor B is the most significant factor. The number of ramming (A) is $36.43 \%$ of the contribution on Permeability. Parameter A is the second significant factor. It was revealed that the number of ramming (A) and percentage of western bentonite with water (C)are having $70.841 \%$ and $14.056 \%$ contributions on hardness. The Taguchi analysis shows that the predicted permeability and Harness are 193.4 at the $90 \%$ confidence level. To confirm the optimum values of estimated control parameters level, the validation test is performed. The casting products are improved based on the estimated control parameters level $\mathrm{A}_{2} \mathrm{~B}_{2} \mathrm{C}_{2}$ and $\mathrm{A}_{1} \mathrm{~B}_{1} \mathrm{C}_{1}$ on hardness and permeability respectively.

\section{REFERENCES}

Abdullah, A., Sulaiman, S., Baharudin, B. T., Ariffin, M. K. A., Vijayaram, T. R., \& Sayuti, M. (2012). Testing for Green Compression Strength and Permeability Properties on the Tailing Sand Samples Gathered from Ex Tin Mines in Perak State, Malaysia. Advanced Materials Research, 445:, 859-864.

Boopathi, S. (2019). Experimental investigation and parameter analysis of LPG refrigeration system using Taguchi method. SN Applied Sciences, 1(8):, 892.

Boopathi, S., \& Myilsamy, S. (2021). Material removal rate and surface roughness study on Near-dry wire electrical discharge Machining process. Materials Today: Proceedings, 45(9):, 8149-8156.

Boopathi, S., \& Sivakumar, K. (2013). Experimental investigation and parameter 
optimization of near-dry wire-cut electrical discharge machining using multi-objective evolutionary algorithm. International Journal of Advanced Manufacturing Technology, 67(9-12):, 2639-2655.

Boopathi, S., \& Sivakumar, K. (2014). Study of water assisted dry wire-cut electrical discharge machining. Indian Journal of Engineering and Materials Sciences, 21(1):, 7582.

Boopathi, S., \& Sivakumar, K. (2016). Optimal parameter prediction of oxygen-mist near-dry Wire-cut EDM. International Journal of Manufacturing Technology and Management, 30(3-4):, 164-178.

Boopathi, S., Sivakumar, K., \& Kalidas, R. (2012). Parametric Study of Dry WEDM Using Taguchi Method. International Journal of Engineering Research and Development (ISSN: 2278-800X), 2(4):, 1-6.

Chang, Y., \& Hocheng, H. (2001). The flowability of bentonite bonded green molding sand. Journal of Materials Processing Technology, 113(1-3):, 238-244.

Desai, B., Mokashi, P., Anand, R. L., Burli, S. B., \& Khandal, S. V. (2016). Effect of Additives on Green Sand Molding Properties using Design of Experiments and Taguchi's Quality Loss Function-An Experimental Study. IOP Conference Series: Materials Science and Engineering, 149(1):, 12006.

Guharaja, S., Haq, A. N., \& Karuppannan, K. M. (2006). Optimization of green sand casting process parameters by using Taguchi's method. The International Journal of Advanced Manufacturing Technology, 30(11):, 1040-1048.

Haribalaji, V, Boopathi, S, and Balamurugan, S. (2015). Effect of welding processes on mechanical and microstructural characteristics of high strength low alloy naval grade steel joints. Defence Technology, 11(3):, 308-317. 
Ihom, A. P., Anbua, E. E., Bam, A., \& Onche, E. (2009). Effects of ramming on the mould properties of Yola natural sand. Continental J. Engineering Sciences, 4:, 20-25.

Kotas, P., Tutum, C., Hattel, J., Šnajdrová, O., \& Thorborg, J. (2010). A casting yield optimization case study: Forging ram. International Journal of Metalcasting, 4(4):, 61-76.

Kumar, S., Satsangi, P. S., \& Prajapati, D. R. (2011). Optimization of green sand casting process parameters of a foundry by using Taguchi's method. The International Journal of Advanced Manufacturing Technology, 55(1-4):, 23-34.

Kumaravadivel, A., \& Natarajan, U. (2013). Application of Six-Sigma DMAIC methodology to sand-casting process with response surface methodology. The International Journal of Advanced Manufacturing Technology, 69(5):, 1403-1420.

Long, B., Phan, N., ... N. C.-A. in M., \& 2016, undefined. (2016). Surface quality analysis of die steels in powder-mixed electrical discharge machining using titan powder in fine machining. Journals.Sagepub.Com, 8(7):, 1-13.

Long, B. T., Phan, N. H., Cuong, N., \& Jatti, V. S. (2016). Optimization of PMEDM process parameter for maximizing material removal rate by Taguchi's method. International Journal of Advanced Manufacturing Technology, 87(5-8):, 1929-1939.

Myilsamy, S., \& Sampath, B. (2021). Experimental Comparison of Near-Dry and Cryogenically Cooled Near-Dry Machining in Wire-cut Electrical Discharge Machining Processes. Surface Topography: Metrology and Properties, 5(9):, in press. http://iopscience.iop.org/article/10.1088/2051-672X/ac15e0

Nandagopal, M., Sivakumar, K., Velmurugan, S., Durairaj, R. B., \& Mageshwaran, G. (2020). Multi-objective optimization of western bentonite (A12H2Na2O13Si4)-blended green sand casting process parameters to improve mould quality. Transactions of the Canadian Society for Mechanical Engineering, 0, 1-10. 
Nguyen, T. D., Nguyen, P. H., \& Banh, L. T. (2019). Die steel surface layer quality improvement in titanium $\mu$-powder mixed die sinking electrical discharge machining. International Journal of Advanced Manufacturing Technology, 100(9-12):, 2637-2651.

Parappagoudar, M. B., Pratihar, D. K., \& Datta, G. L. (2007a). Linear and non-linear statistical modelling of green sand mould system. International Journal of Cast Metals Research, 20(1):, 1-13.

Parappagoudar, M. B., Pratihar, D. K., \& Datta, G. L. (2007b). Non-linear modelling using central composite design to predict green sand mould properties. Proceedings of the Institution of Mechanical Engineers, Part B: Journal of Engineering Manufacture, 221(5):, $881-895$.

Pattnaik, S., Karunakar, D. B., \& Jha, P. K. (2013). Optimization of multiple responses in the lost wax process using Taguchi method and grey relational analysis. Proceedings of the Institution of Mechanical Engineers, Part L: Journal of Materials: Design and Applications, 227(2):, 156-167.

Pulivarti, S. R., \& Birru, A. K. (2018). Optimization of green sand mould system using Taguchi based grey relational analysis. China Foundry, 15(2):, 152-159.

Sampath, B., \& Myilsamy, S. (2021). Experimental Investigation of a Cryogenically Cooled Oxygen-mist Near-dry Wire-cut Electrical Discharge Machining Process. Strojniški Vestnik - Journal of Mechanical Engineering, 67(6):, 322-330.

Santhosh, A. J., \& Lakshmanan, A. R. (2016). Investigation of ductile iron casting process parameters using Taguchi approach and response surface methodology. China Foundry, 13(5):, 352-360. 